\title{
Marketing communication for LGBT in Thailand Tourism Industry: A preliminary Findings
}

\author{
Supitcha Pornsuksawat ${ }^{1 *}$, Jantima Kheokao ${ }^{2}$ \\ ${ }^{1}$ D.Com.Arts in Marketing Communication (candidate) in the school of Communication Arts, University of the Thai \\ chamber of commerce, Thailand \\ ${ }^{2}$ Associate Professor and Director of the Doctoral Program In Marketing Communication, school of Communication \\ Arts, University of the Thai chamber of commerce, Thailand
}

\begin{abstract}
This research is aimed to indicate the significance of marketing communication in order to promote tourism based on LGBT tourists by using representative sample. The research is published on EBSCO database. As a result, the sample relates to six subjects, which reveals that the study of SMCR Model (Berlo,1960) has the highest number of research; First, media receptor (R) in four subjects (66.67\%). Second, sender (s) and channel (c) in only one subject (16.67\%). The last one is media (M). The three main theories in the research; the first one is Tourist behavior in five subjects $(83.33 \%)$, the second one is the inspiration in four subjects $(66.67 \%)$ and the last one is the attitude in two subjects $(33.33 \%)$. The researchers used three different methods: Quantitative research, Qualitative research and Mix methodology. The researcher team mainly used quantitative research in four subjects $(66.67 \%)$ and merely used qualitative research and mix methodology in only one subject for each $(16.67 \%)$.
\end{abstract}

Keywords: LGBT, LGBT tourism, Thailand tourism 


\section{Introduction}

The Marketing Communication is the main strategy for business to achieve customer's goal. However, the business still cannot read customer's mind about their desirable products and services without marketing strategy. Apart from this communication, it can play an important role in tourism industry to improve the relationship between clients and business. As a result, a business can compete to other countries.

Marketing Communication of Tourism in Thailand has recently started in 2018 and accepted to be "the new shade of color" (Fedder, 2015) is marketing campaign that designed to create new perspective in tourist attraction by using website to communicate directly to customers and it interests many travel agency business because many people are prone to use website more than other channels. As a result, they can reach to the targeted group of customer, LGBT group. The marketing communication will be different relating to many factors such as society and culture. The LGBT tourists may want to travel and enjoy activities with their gay friends in case they are men (Cahill et al., 2013). Nowadays, gay or homosexual have played an important role in society and interest many business in Thailand. It is a well-known fact that they have high purchasing power so they look for travel agencies that are suitable for them and travel agency in Thailand is quite approachable for them. However, some people still look down on the LGBT tourists, so they are not satisfied to participate in activities and recreation of tourism. Many travel agencies in Thailand are trying to respond their needs by improving marketing strategy and using Marketing Communication to serve them.

According to the previous factors, the research must relate to the marketing communication that promotes tourism to the LGBT tourists in order to clarify the basic information. As a result, the researcher will understand the role of marketing communication and can point out the weakness of this strategy to improve another research in the near future.

\section{The objectives}

Pointing out the significance of marketing communication in order to promote tourism based on LGBT tourists.

\section{Scope of the research}

The researcher has determined the scope by followings:

1. Duration of time: the information must be published on EBSCO in 2008-2018 
2. Scope of information: Research about the tourism of LGBT tourists including tourism behavior, tourist attraction or hotel determination, demand and expectation by using three methods: 1.The study of SMCR Model (Berlo, 1960) 2. The theories 3. Methodology

\section{Research synthesis methods}

1. Population and representative sample

The research, which are mainly about marketing information that promote tourism for LGBT tourists, is published on EBSCO database in 2011-2018 with six subjects.

2. Researching methods

2.1 Gathering information from EBSCO database to find research that relate to the tourism of LGBT tourists including tourism behavior, tourist attraction or hotel determination, demand and expectation by searching these phrases: LGBT tourism, Lesbian tourism, Gay tourism, Bisexual tourism, Transgender tourism and Homosexual tourism and the research must be published in 2011-2018, which represents in this table below.

Table 1:

\begin{tabular}{ccc}
\hline Keywords & Number of papers & $\begin{array}{c}\text { Number of paper related to } \\
\text { tourism behavior }\end{array}$ \\
\hline LGBT tourism & 45 & 2 \\
\hline Lesbian tourism & 6 & 2 \\
\hline Gay tourism & 71 & 0 \\
\hline Bisexual tourism & 0 & 0 \\
\hline Transgender tourism & 2 & 0 \\
\hline Tomosexual tourism & 1 & 9 \\
\hline
\end{tabular}

3. Research Instrument and quality testing

The research instrument: Record form of marketing information that promotes tourism for LGBT tourists. The researcher has synthesized by gathering information from secondary sources by these following methods;

3.1 Interpreting data from documents and textbooks as a guideline and conclude research details. 


\subsection{Creating record form}

3.3 Rechecking record form by three specialists to find content validity using Index of Item Objective Congruence: IOC, which is 0.98

3.4 Adjusting record form according to the suggestion from specialists.

4. Data Analysis

Analyzing data from the record form by evaluating descriptive statistics and content analysis, providing results of quantitative research and qualitative research, presenting by essay with demonstrated table.

\section{Conceptual framework}

The research of marketing information that promotes tourism for LGBT tourists. The researcher will present ideas in three ways: the study of SMCR Model (Berlo, 1960), idea, theories and methodology in research can represent in this picture below.

\begin{tabular}{|l|l|l|}
\hline $\begin{array}{l}\text { Research related to } \\
\text { marketing communication } \\
\text { to promote tourism among } \\
\text { LGBT tourists. }\end{array}$ & $\begin{array}{l}\text { Education issues } \\
-\quad \text { Elements of } \\
\text { SMCR communication } \\
\text { (Berio, } \\
1960) \\
-\quad \text { Concepts and } \\
\text { theories used in research } \\
-\quad \text { Research } \\
\text { methodology }\end{array}$ \\
\hline
\end{tabular}




\section{Data Synthesis Results}

\section{The study of SMCR Model (Berlo, 1960)}

According to the six subjects, shows that the highest number of research is media receptor $(\mathrm{R})$ in four subjects (66.67\%), the second is sender (s) and media (M) in only one subject $(16.67 \%)$ and the last one is channel without any research $(0 \%)$. The number of research can represented in this table below.

Table 2 :

\begin{tabular}{ccc}
\hline S-M-C-R Model & Number of papers & percentage \\
\hline Sender & 1 & 16.67 \\
Message & 1 & 16.67 \\
Channel & 0 & 0 \\
Receivers & 4 & 66.67 \\
\hline
\end{tabular}

Sender (S)-According to the research of six subjects, shows that researcher has mainly studied about improving marketing strategy by study the LGBT tourists' needs and adjust these information to process in marketing communication strategy of sender.

Media (M)-According to the research, shows that researcher has mainly studied about being friend with gay to attract tourists.

Channel (C)-

Receiver (R)-The research is aimed to study about receiver in different subjects; 1.Media accessibility and integrated marketing communication of tourists 2 . Interaction of marketing communication 3.Opinion and influence of quality service 4.Personal factors of tourist and marketing factors that affect tourism

\section{Ideas and theories of the research}

Ideas and theories of the research; the first one is Tourist behavior in five subjects $(83.33 \%)$, the second one is the inspiration in four subjects $(66.67 \%)$ and the last one is the attitude in two subjects $(33.33 \%)$. The theory of marketing components and ideas of LGBT tourists $(16.67 \%$ ) shows that many people are interested in LGBT tourists but there are small amount of research about these tourists. The communication is an important tool that can persuade tourism for tourists and marketing theory is quite important because the LGBT tourism is growing continuously and the LGBT are starting to be accepted in society nowadays. As a result, the researcher will use marketing communication to communicate with tourists easier. 


\section{Researching methods}

According to six subjects of the research, reveals that the research are mostly quantitative research in four subjects (66.67\%). Qualitative research and mix methodology are used in only one subject for each. The qualitative research methods can be divided into four types: In-depth semi-structured interview, group interview, group discussion and document synthesis.

\section{Conclusion}

This research is mainly about marketing information that promotes tourism for LGBT tourists, is published in 2011-2018. The result shows that the LGBT tourists are not different from male and female tourists in many ways: transportation and expectation. They expect that tourist attraction to have its own identity and interesting background. Moreover, the place must be convenient to go and safe. Also, the hotel is expected to be convenient and surrounded by good atmosphere more than other gender in order to relax, abscond from chaos and learn local cultures.

1. Main idea of SMCR model study (Berlo, 1960).

As a result, the research synthesis of six subjects reveals that the highest number of research is media receptor (R) in four subjects (66.67\%). The study of sender (s) and channel (c) in only one subject (16.67\%). the last one is channel without any research. The LGBT tourists are quite new to the market. In addition, communication is very important to achieve the customers' goal, so the good communication must including these four components. We suggest other researcher to make more research about sender, media and channel.

2. Ideas of knowledge and theories

The three main theories in the research; the first one is Tourist behavior in five subjects (83.33\%), the second one is the inspiration in four subjects (66.67\%) and the last one is the attitude in two subjects (33.33\%). The theory of marketing components and ideas of LGBT tourists $(16.67 \%)$ shows that many people are interested in LGBT tourists. Nowadays, there are few research about these topics. The communication is an important tool that can persuade tourism for tourists and marketing theory is quite important because the LGBT tourism is 
growing continuously and the LGBT are starting to be accepted in society nowadays. As a result, the researcher will use marketing communication to communicate with tourists easier.

3. Methodology

The research has used three different methods: Quantitative research, Qualitative research and Mix methodology. The researcher has mainly used quantitative research in four subjects (66.67\%) and merely used qualitative research and mix methodology (21.43\%). The least quantitative research is $16.67 \%$.

The quantitative research itself is not enough to understand LGBT tourist needs. The qualitative research can explain the in-depth data. Nowadays, the mix methodology is being used in order to eliminate weakness in other kind of research. We may receive clear and completed information. The mix methodology is the best method that based on philosophy and action research. In the near future, the qualitative research and the mix methodology can adapt in many ways.

\section{References}

Anand, T., Nitpolprasert, C., Ananworanich, J., Pakam, C., Nonenoy, S., Jantarapakde, J.\& Phanuphak, N. (2015). Innovative strategies using communications technologies to engage gay men and other men who have sex with men into early HIV testing and treatment in Thailand. Journal of virus eradication, 1(2), 111.

Apostolopoulou \& Elia-Nikoleta, 2016. Gay and Lesbian Tourism- in search of gay space?.

University of the Aegean.

Arianna Anzaloni (2018, March 12). Euromonitor International Reveals the World's Top City Destinations in 2018. [Blog]. Retrieved from

https://blog.euromonitor.com/euromonitorinternational-reveals-the-worlds-top-city-destinations-in-2018/

Barr, S. M., Budge, S. L., \& Adelson, J. L. (2016). Transgender community belongingness as a mediator between strength of transgender identity and well-being. Journal of counseling psychology, 63(1), 87. 
Being LGBT in Asia, (2018). Thailand Country Report. Retrieved from:

http://www.asiapacific.undp.org/content/dam/rbap/docs/Research\%20\&\%20Publications/ hiv_aids/rbaphhd-2014-blia-thailand-country-report.pdf

Belem Barbosa, Thiago Cobral De Moraes \& Anabela Rocha, 2017. Rio de Janeiro as a gayfriendly destination : The gay tourists' perspective.

Beyondblue.org.au (2018). Factors affecting LGBTI people. Retrieved from: https://www.beyondblue.org.au/who-does-it-affect/lesbian-gay-bi-trans-andintersexlgbti-people/factors-affecting-lgbti-people

Cahill, S., Valadéz, R., \& Ibarrola, S. (2013). Community-based HIV prevention interventions that combat anti-gay stigma for men who have sex with men and for transgender women. Journal of public health policy, 34(1), 69-81.

Carlos Monterrubio \& Mercy D. Barrios, 2016. Lesbians as tourists : A qualitative study of tourist motivations in Mexico.

Cohen, E. 1979. “A Phenomenology of Tourist Experience”, p. 183-190.

Fedder, C., (2015). How to engage LGBT consumers in marketing communications. Retrieved from: https://www.quirks.com/articles/how-to-engage-lgbt-consumers-inmarketingcommunications.

Gray, H. (2014). Negotiating Invisibility: Addressing LGBT Prejudice in China, Hong Kong, and Thailand.

Hildebrand, D., DeMotta, Y., Sen, S. \& Kongsompong, K., (2013). In-group and out-group influences on the consumption behavior of minority groups: The case of gay men. Journal of Public Policy \& Marketing, 32(special issue),70-78.

IGLTA. (2015). Tourism Authority of Thailand. Retrieved from: https://www.iglta.org/tourismthailand/.

Kang, D. B. C. (2017). Eastern orientations: Thai middle-class gay desire for 'white Asians'. Culture, Theory and Critique, 58(2), 182-208.

Lin, Y. J., \& Israel, T. (2012). Development and validation of a psychological sense of LGBT community scale. Journal of Community Psychology, 40(5), 573-587.

Lonely planet. (2018). Gay \& Lesbian Travellers. Retrieved from:

https://www.lonelyplanet.com/thailand/gay-and-lesbian-travellers. 
Pata.org, (2018). The Connected Visitor Economy Bulletin. Retrieved from:https://pata.org/store/wp-content/uploads/2016/10/VE-October-2016.pdf

Sullivan, G. \& Jackson, P.A., (2013). Gay and lesbian Asia: Culture, identity, community. UK: Routledge.

Waitt, G., \& Markwell, K. (2014). Gay tourism: Culture and context. Routledge.

Wong, C. C. L., \& Tolkach, D. (2017). Travel preferences of Asian gay men. Asia Pacific Journal of Tourism Research, 22(6), 579-591.

World Tourism Organization (2012). Global Report on LGBT Tourism. Retrieved from: https://www.e-unwto.org/doi/pdf/10.18111/9789284414581.

Wu, M.Y. and Pearce, P. (2018). Factors Affecting How Young Hosts Welcome Tourists: An Asian

Case Study. In Managing Asian Destinations (241-260). Springer, Singapore 